\title{
Critical Corpus Analysis of ALTs' Online Discourse
}

\section{Hugh Kirkwood \\ Kitasato University}

\section{Reference Data}

Kirkwood, H. (2021) Critical corpus analysis of ALTs' online discourse. In P. Clements, R. Derrah, \& P. Ferguson (Eds.), Communities of teachers \& learners. JALT. https://doi.org/10.37546/ JALTPCP2020-23

Thousands of non-Japanese nationals work as assistant language teachers (ALTS) in schools throughout Japan. To better understand ALTs' teaching contexts and motivations, the researcher created a corpus of online discourse about ALTs and used corpus software to identify and analyse key words in context. He also asked questions from critical discourse analysis to examine the relationship of these key words to ideology and power. The findings were that while the discourse often described poor employment conditions and problems for ALTs working in Japanese schools, the discourse itself may also be contributing to the reproduction of these conditions. This is because it seemed to both stigmatise ALTs as fundamentally unprofessional and suggest that ALT positions can be a step towards other types of employment in Japan. Such discourse may encourage people to become ALTs and tolerate poor conditions in the short-term instead of engaging in collective actions to make long-term improvements.

日本で外国語指導助手 (ALT) として働く外国籍労働者は何千といる。ALTが働〉環境亡動機付けを理解するため、筆者は ALTに関するディスコースのコーパスを構築し、コーパス分析ソフトを用いて文脈中のキーワードの特定と分析を行つた。ま た批判的言説分析を用いて、抽出されたキーワードとイデオロギー及び影響力の関係を検証した。結果、ディスコースには ALTの劣悪な学働環境と日本の学校で働く上での問題が多くみられた一方で、デイスコース自体がこうした状況の再生産に寄 与している可能性が示唆された。ディスコースにより、ALTは基本的に高度な專門性を必要としないというスティグマを形成し うることに加え、ALTは日本で他の職を得るためのステップとなりうることが示唆されているようであった。このようなディスコ 一スは長期的な状況改善のための集団的行動を起こすのではなく、ALTが短期的に現状に我慢することを促している可能性 がある。 ssistant language teachers (ALTs) are often native English speakers hired to support A language teaching and facilitate cultural exchange in Japanese schools (Ohtani, 2010; Yokoyama, 2018). There were 11,439 ALTs working in public Japanese elementary schools in 2015 (MEXT, 2016a). In public junior high schools there were 7,282 (MEXT, 2016b) and in public high schools there were 3,409 (MEXT, 2016c). Typically, ALTs are not expected to have language teaching qualifications, which Ohtani (2010) and Yokoyama (2018) have criticised. However, while it is important to pay attention to hiring practices, it is also important to learn from teachers themselves about the factors that influence how they teach and how they use the knowledge and experience they gain through teaching. This paper describes an attempt to do this through analysis of ALTs online discourse.

While research exploring ALTs' perspectives on their employment exists, (see McConnell 2000), it is hard to find work that is not focused on the government Japan Exchange and Teaching (JET) Programme. In the past 20 years, the proportion of ALTs hired by JET has decreased and more of them are now hired by dispatch companies, which are privately operated contractors (Flynn, 2009; Hougham et al., 2017). In 2015, the percentage of ALTs working for dispatch companies in public elementary schools was 24.6\% (MEXT, 2016a), in public junior high schools it was 38.3\% (MEXT, 2016b), and in public senior high schools it was $15.5 \%$ (MEXT, 2016c). According to Flynn (2009), these companies offer lower salaries and reduced employment benefits in comparison with the JET Programme. Dispatch ALTs are also often restricted in the type of working relationships they are permitted to have with other teachers in their schools (Hougham et al., 2017). For these reasons, dispatch ALTs' experiences should not be overlooked. In addition, a critical analysis of online discourse that includes perspectives from all types of ALTs and former ALTs may also help to explain why, despite the negative information shared online about dispatch companies, people still apply to work for them. 


\section{Critical Corpus Analysis of Online Discourse}

The term critical is not intended to disparage existing or former ALTs. In this paper, critical is used as it is in critical discourse analysis (CDA), particularly Norman Fairclough's (2001) version, which is in "the special sense of aiming to show up connections that may be hidden from people - such as the connections between language, power and ideology" (p. 4). This method provides different insights to research based on interviews or surveys because it is not based on participants' replies to researchers' questions. Instead, Fairclough's (2001) CDA directs questions towards language itself, examining how discourse participants use language to do things and how what they do relates to inequalities in the wider society. His approach is critical of the influence of power on language, but it is also critical of the way language can reproduce systems of power.

A personal reason why I do not use the word critical to disparage ALTs is that I was one myself and worked for a dispatch company for seven years. It is through this experience that $\mathrm{I}$ became interested in online discourse and attracted to CDA as a research approach. When I was an ALT, I found the unguarded and frank assessments of ALT employment that I read on discussion forums resonated with my experiences. Now, I feel that academic literature about ALTs does not emphasise these perspectives enough. Fairclough's (2001) position that language use in discourse helps to shape society also resonates with me because I was influenced by online discourse to seek qualifications and become a university teacher. However, there are two main limitations to my research approach that should be made clear. First, many online discourse participants use pseudonyms. This may result in them being less inhibited when discussing sensitive topics, but it is difficult to judge if they are who they claim to be. Therefore, readers should not automatically assume the content of the discourse described in this paper is true or represents the opinions and experiences of all ALTs (dispatch and non-dispatch). Second, my personal experiences are also a source of bias that have influenced my interpretations of ALTs' language and its connection to society. For Fairclough (2001), avoiding such bias is impossible and therefore the best CDA researchers can do is make their biases transparent. To do this, I will give more details about myself later in the paper.

However, according to Widdowson (1998), simply describing bias is not enough. $\mathrm{He}$ criticised CDA researchers, particularly Fairclough, for selectively analysing texts that confirmed their existing assumptions about society. One response to this criticism, and this is the approach $\mathrm{I}$ have taken in this paper, has been to incorporate corpus-based approaches into CDA because they involve using software to help researchers determine which texts or parts of text they should subject to a closer reading (O'Halloran, 2010). This is done by creating and performing analysis on a corpus, which is a body of texts that represents "a language or some part of a language" (Biber et al., 1998, p. 246). Researchers can use corpus software to generate key word lists, which include words found to "occur with unusual frequency" (Scott, 2010, p. 149). The software can then be used to sample and view these words in context. This gives information about the ways the words are used across texts, which makes it less likely that CDA researchers will be tempted by personal biases to focus on the uses of language that are not representative of broader trends (O’Halloran, 2010).

\section{Research Questions and Research Procedure}

The research questions were:

RQ1. What are the key words in a corpus of discourse about ALTs?

RQ2. What is suggested by critical analysis of these key words in context?

In February 2019, I created a corpus of 287,378 words using data from r/ teachinginjapan (https://www.reddit.com/r/teachinginjapan/). It is a space on Reddit, which is a forum website used by millions of users, particularly English speakers (Leuckert \& Leuckert, 2020). With over 24,000 subscribers, r/teachinginjapan contains a large amount of discourse about ALTs. Reddit is structured into initial posts (comments) and responses (replies). To keep my corpus relevant to discourse on ALTs, I used Reddit's search functions to only display the comments from $\mathrm{r} /$ teachinginjapan that included the word ALT. Next, to display comments that appeared to provoke more interested responses, I used Reddit's search functions to rank the comments from my search according to the number of replies they generated. I then downloaded the text from the 100 comments with the highest number of replies. I also downloaded the text of the replies that followed these comments.

After I created my corpus, I used the corpus software AntConc 3.5.8 (Anthony, 2019) to calculate the frequency of each word in the corpus. I then compared these frequencies with the frequencies of the same words in a reference corpus, which is a corpus designed to represent usual language (Scott, 2010). For this, I used the British National Corpus (BNC) (BNC Consortium, 2007). Comparison is necessary to create a key word list because the statistical tests used to determine whether word frequencies are unusual or not require the input of frequencies considered to be usual (Scott, 2010). The outputs of these tests show high positive keyness, which indicates that a word has occurred in the 
corpus with an unusually high frequency. Conversely, a high negative keyness indicates the frequency of that word is unusually low (Scott, 2010). I created a key word list (see Table 1 for a sample of this) with words ranked by positive keyness values. The corpus software determined these values with Dunnings's (1993) Log-likelihood test.

After generating the key word list, I examined concordance lines, which show each instance of a word or word stem (e.g., "teach-" for teach/teacher/teaching) in the context of text preceding and following it (Sinclair, 1999). I chose to display 50 characters both preceding and following each key word. I exported these lines to a spreadsheet and randomised them because the standard output of the corpus software groups concordance lines according to the first letters of words to the right of the key word. I then labeled them with my interpretation of how the key word was used. For example, if the text preceding "ALT" was "low wages in", I labeled it "low pay." As I did this for each concordance line, I also thought about questions from Fairclough's (2001) version of CDA to investigate the relationship of the discourse to the working conditions of dispatch and non-dispatch ALTs. In most cases I stopped labeling after 150 lines, but in other cases I stopped after 75. I based these decisions on Sinclair's (1999) suggestion that corpus researchers can stop categorizing concordance lines when new patterns do not emerge.

Regarding the ethics of this research, because $\mathrm{r} /$ teachinginjapan is publicly accessible and its users use pseudonyms, I did not obtain consent from users. However, Mackenzie (2017) suggested that research of online discourse may have the potential to cause harm by drawing unwanted attention to people's online personas. Therefore, this paper does not include direct quotations from the participants or refer to their usernames. I also redacted the name of a dispatch company to avoid causing problems to its employees.

\section{Findings}

As described above, I used corpus software to compare the corpus of ALTs' online discourse with a reference corpus to generate a key word list. The results of this provide an answer to the first research question, "What are the key words in a corpus of discourse about ALTs?"
Table 1

Key Words Ranked by Keyness in the r/teachinginjapan ALT Corpus

\begin{tabular}{cccc}
\hline Rank & Frequency & Keyness (Log-likelihood) & Key word \\
\hline $\mathbf{1}$ & 893 & +9265.67 & alt \\
$\mathbf{2}$ & 588 & +6873.99 & REDACTED $^{\text {a }}$ \\
$\mathbf{3}$ & 1074 & +6706.22 & Japan \\
$\mathbf{4}$ & 6697 & +6267.14 & $\mathrm{I}$ \\
$\mathbf{5}$ & 449 & +5193.79 & alts \\
$\mathbf{6}$ & 5350 & +4958.45 & you \\
$\mathbf{7}$ & 928 & +4738.72 & teaching \\
$\mathbf{8}$ & 784 & +4318.32 & Japanese \\
$\mathbf{9}$ & 361 & +4219.96 & eikaiwa \\
$\mathbf{1 0}$ & 427 & +4006.02 & dispatch \\
\hline
\end{tabular}

Note. ${ }^{\mathrm{a}} \mathrm{A}$ dispatch company name was redacted to avoid causing harm to discourse participants.

The second research question of this study was "What is suggested by critical analysis of these key words in context?" To answer this question in a way that fits the confines of this publication, I focused my attention on the ten words shown in Table 1 with the highest positive keyness in the context of concordance lines. From this analysis three topics emerged from the data. These themes are: (a) negative evaluations of being an ALT, (b) pronoun use for giving advice, and (c) stepping-stone narratives. I will explain each of these themes in more detail below.

However, before describing these themes, I should mention a problem with my methodology. In feedback to my JALT 2020 video presentation, my PhD supervisors pointed out to me that the BNC is mostly composed of written texts that may differ greatly in form compared to the language used online (N. Groom and P. Thompson, personal communication, November 12, 2020). Therefore, to check if the attention I paid to the themes above was justified or not, I created a new key word list through comparing the corpus of ALTs' online discourse with an alternative reference corpus. This was a 10-million-word Reddit corpus made by creators of the software ConvoKit (Version 2.4.3) (Chang et al. 2020a; Chang et al. 2020b), it is available through this software and was sampled from the larger Reddit Corpus created by Baumgartner (2019). All the key words I 
examined when exploring the second research question feature in this list, however, not all of them have positions in the top 10.

\section{Negative Evaluations of Being an ALT}

The main reason why I redacted the name of the dispatch company, was that, in the sample I took of its use in 150 concordance lines, 29 of its uses involved evaluating it as "bad" or "shitty." The company name was also linked in a further 11 lines to what discourse participants considered to be a poor salary. Such complaints were also directed at other employers. 13 out of 150 uses of "ALT-" also described low pay. In the broader discourse, the yearly salaries for dispatch ALTs were often stated to be around $¥ 2,400,000$ a year, which is about $55 \%$ of the 2019 average yearly salary of $¥ 4,402,228$ for people working fulltime hours in Japan (OECD, 2021).

The key word "dispatch" itself was also used in negative evaluations. There were 18 out of 150 lines sampled for the word that referred to the contracts made between dispatch companies and local government boards of education (BOEs) in Japan. Discourse participants expressed anger regarding the cuts taken by dispatch companies from the amount of money paid by the BOEs for each ALT. They also voiced displeasure about the exclusion of dispatch ALTs from employment benefits they claimed workers are legally entitled to, such as enrollment in company health insurance schemes. Flynn (2009) described these issues over ten years ago and the discourse suggests his criticism is still relevant at the time of writing. The online discourse also suggests the situation is getting worse as 13 out of 150 uses of "dispatch" referred to complaints about an increasing number of BOEs choosing to use dispatch companies rather than directly hire ALTs to avoid responsibility for their management.

"Eikaiwa" is another key word that is relevant when discussing negative evaluations of working conditions. It is a Japanese word meaning "English conversation," but it also refers to private language schools where students are usually taught by native English speakers. It does not refer to ALT work, but it is a key word in ALTs' online discourse because it is an alternative form of employment considered by participants thinking about becoming ALTs. Many participants also argued that eikaiwa employment conditions and hiring requirements were equivalent to ALT dispatch companies. By themselves, such comparisons may be negative evaluations of ALT employment as eikaiwa schools have often been criticised for prioritizing profits over employee welfare and students' learning (Nuske, 2014). This claim is supported by 23 out of 150 lines sampled that included statements about the equivalency of eikaiwa and dispatch ALT positions and most of these described both types of employment in negative terms.
Apart from dispatch ALT employment conditions, other negative evaluations described wider issues in the Japanese education system and (dispatch and non-dispatch) ALTs' poor relationships with other teachers. For example, 18 out of 150 uses of "teach-" referred to problems with Japanese coworkers. Such problems have been described by Hougham et al. (2017) and Kano et al. (2016), who described cultural misunderstandings and ALTs' frustrations with their Japanese coworkers' English proficiency and teaching approaches. Beyond grievances with individuals, however, there were suggestions that English language education is fundamentally broken in Japan. There were 11 out of 150 lines sampled that used "Japan-" when expressing such a pessimistic outlook. Participants questioned whether ALTs could provide benefits to learners when these learners were motivated more to use English to pass examinations than to communicate with English speakers.

Regarding discourse about dispatch and non-dispatch ALTs themselves, 150 of the uses of the key word "ALT" described ALTs as having "low status." Again, this was often done to criticise the Japanese education system, but criticism was also leveled at the ALTs themselves. Individual ALTs were condemned for engaging in unprofessional behavior while teaching, being culturally insensitive, and acting in ways that brought other ALTs into disrepute. Some participants also argued that, by choosing to work in schools without teaching qualifications, all ALTs were contributing to problems with language teaching in Japan. Seven out of 150 lines sampled from uses of "teach-" referred to ALTs in this way and questioned whether they deserved to be labeled as teachers. Generally, this criticism did not appear to be constructive in the sense of trying to improve the quality of ALTs or their teaching, instead it either had the purpose of warning "real" teachers away from ALT positions or encouraging existing ALTs to change careers.

\section{Pronoun Use and Advice Giving}

The pronouns "l" and "you" feature as key words in Table 1, but this may have been the result of a flawed decision to use the BNC as a reference corpus. In my revised key word list, created through comparison with a Reddit reference corpus, "l" and "you" did not remain in the top 10 positions of the key word ranking, but they were still key words occurring with unusually high frequency. To examine why this was the case, I analyzed the pronouns in context and found they were used to give advice. They occurred in structures similar to "I think $x$ " or "you should $y$." Twenty-four out of 75 concordance lines sampled for uses of "I" fit this description. This was also the case for 63 out of 75 lines sampled from uses of "you." Out of the 63 examples of advice giving related to "you", 48 involved giving advice about ALT employment. These uses were related to 
becoming an ALT or changing jobs afterwards. The prevalence of giving advice about careers was also indicated by 19 out of 150 lines sampled for "teach-." This will not be a surprise for readers of $\mathrm{r} /$ teachinginjapan as initial comments in the subreddit are often requests for information about potential employment or requests for advice about ongoing work-related problems.

Nevertheless, beyond the unsurprising finding that people often give advice on online forums, a critical discourse analysis can reveal details concerning this advice and what it suggests about the wider society. Fairclough (2001) described how in English "you" is often used to strike a personal tone when communicating to audiences. Such personalization might have occurred in this corpus when users of $r$ /teachinginjapan gave advice related to ALTs; however, looking at concordance lines where "you" also occurred with "I" it appeared to play the role of positioning advice givers above the receivers. According to Locher and Limberg (2012), when investigating advice, hierarchical relations should be considered even in peer-to-peer contexts because "an advice-seeker positions the advice-giver in a role of having something to say about the issue raised" (p. 6). Advice-givers often demonstrate they have the right to do this by explaining their expertise (Locher \& Limberg, 2012). However, in the ALT online discourse, many advice givers seemed particularly assertive in explaining why they were "experts," which made me unsure if they were assuming "expert" status to give advice or if they were giving advice to assume "expert" status.

Another pronoun discussed by Fairclough (2001) was "we" and its use to express solidarity with the recipients of discourse. For example, "We should boycott ALT dispatch companies" could be an expression of such solidarity. In fact, such actions and communications about other forms of collective action including references to unions were mentioned in the $\mathrm{r} / \mathrm{teachinginjapan} \mathrm{corpus,} \mathrm{but} \mathrm{in} \mathrm{the} \mathrm{key} \mathrm{word} \mathrm{lists} \mathrm{generated}$ from a comparison between the corpus of ALTs' online discourse with both the BNC and the alternative reference corpus, "we" had negative keyness. This means "we" was used with relatively low frequency in comparison to the reference corpus, which suggests an orientation not on collective action, but on ALTs acting in isolation. Rather than acting with others to improve ALTs' contexts, the discourse more broadly suggested that individuals should follow the advice described by their "expert" peers to focus on improving their skills and qualifications and move out of ALT employment.

\section{"Stepping-Stone" Narratives}

Evidence for a focus on individual improvement rather than on collective action did not only come from examining the unusually low frequency of "we." Advice with this focus was overtly stated in 7 out of 150 concordance lines sampled for uses of "alt-", 8 out of 150 lines for uses of the redacted company name, and 7 out of 150 uses of dispatch. Discourse about becoming qualified was also connected to 17 out of 150 uses of "teach-." Reading this advice in the context of the comments and replies from which they were taken, I began to find that narratives similar to "ALT jobs are only a stepping-stone to something better" were often repeated. For example, I read examples of "experts" explaining to prospective ALTs how spare time in the ALT's working day could be used to study Japanese or gain qualifications in order to change employment. I also read examples of people with teaching qualifications or people working in higher status nonteaching positions being mocked by "experts" for considering ALT positions. In other words, many examples of advice in the corpus suggest that ALT positions only have value for people without Japanese skills or qualifications who want to live in Japan and need a job to provide them with a visa and living expenses before they are ready to move on to something else. There appeared to be little interest in advice about improving ALTs' ability to teach within Japanese schools, which was suggested by only 7 out of 150 uses of "teach-" referring to classroom practice compared to the 17 out of 150 uses referring to qualifications mentioned above and an additional 19 out of 150 uses referring to more general discussions about careers.

\section{Conclusions}

As stated in the description of the research procedure, this study involves my own interpretations of language use. Readers should be aware of my own biases, which mostly stem from dissatisfaction with some of the conditions of being a dispatch ALT. Nevertheless, my employment history also gives me an insider position that may have had a positive effect on my ability to understand the discourse and its context. I should also repeat that the data itself may not represent all types of ALTs or the conditions of ALTs working today. For example, since I collected the data before COVID-19 spread widely within Japan, there is nothing in my data about the effects of the pandemic on ALTs' lives. To gain a fuller picture of ALTs' position within the Japanese education system, more research including different types of research, such as surveys and interviews, is also required. 
What then does my research suggest could be an area for further research or an area for change? In the first part of my answer to "What is suggested by critical analysis of these key words in context?" I focused on negative evaluations of ALT positions. Since many of these complaints referred to dissatisfaction with the terms of dispatch ALT employment, this suggests that researchers and policy makers should pay more attention to the employment conditions of these teachers. Another type of complaint applied to all ALTs and questioned the validity of the position of ALTs within Japanese schools. While it is possible these complaints are the consequence of cultural misunderstandings or personal grievances, it is important for CDA researchers to report on what discourse participants write and appear to care about. Furthermore, complaints about employment terms and the status of ALTs may be related. If all ALTs are stigmatised as offering little value to Japanese education, current ALTs may be less likely to fight for their rights or be selective about their employers. In other words, online discourse may not only describe negative employment conditions, but also help to reproduce such conditions.

In the second and third part of my answer to the research question. I argued that in the corpus of ALTs' online discourse there is a focus on advice promoting individual rather than collective action. I described "stepping-stone narratives", which I consider to be problematic because they suggest ALTs' influence on the Japanese language education and their employment conditions do not matter because their positions are only meant to be a temporary step towards something better. Nevertheless, I cannot suggest people engaging in and reading such discourse completely ignore these "stepping-stone" narratives without being a hypocrite as I have personally benefitted from following "expert" advice on forums to change careers. Therefore, at present, the only message I have for ALTs is that I hope that they can, more than I did, collaborate both online and offline to make a better contribution to redefining what ALT employment is and what it does.

\section{Bio Data}

Hugh Kirkwood teaches English at Kitasato University. He is also working on a PhD in applied linguistics at the University of Birmingham examining the relationship of online discourse to teachers' ideology and employment conditions. <kirkwood@kitasato-u.ac.jp>

\section{References}

Anthony, L. (2019). AntConc (3.5.8) [Computer software]. Waseda University. Retrieved from https://www.laurenceanthony.net/software

Biber, D., Conrad, S., \& Reppen, R. (1998). Corpus linguistics: Investigating language structure and use. Cambridge University Press. https://doi.org/10.1017/CBO9780511804489

BNC Consortium. (2007). British national corpus, XML edition. Oxford University Computing Services. Retrieved from http://hdl.handle.net/20.500.12024/2554

Baumgartner, J. (2019). Reddit corpus. Available from https://files.pushshift.io/reddit/

Chang, J. P., Chiam, C., Fu, L., Wang, A., Zhang, J., \& Danescu-Niculescu-Mizil, C. (2020a). ConvoKit (2.4.3) [Computer software]. Cornell University. Available from https://convokit.cornell.edu/ documentation/

Chang, J. P., Chiam, C., Fu, L., Wang, A., Zhang, J., \& Danescu-Niculescu-Mizil, C. (2020b). ConvoKit: A toolkit for the analysis of conversations. In O. Pietquin, S. Muresan, V. Chen, C. Kennington, D. Vandyke, N. Dethlefs, K. Inoue, E. Ekstedt, \& S. Ultes. (Eds.) Proceedings of the 21 th annual meeting of the special interest group on discourse and dialogue, 57-60. Retrieved from https://www.aclweb.org/anthology/2020.sigdial-1.8

Dunning, T. (1993). Accurate methods for the statistics of surprise and coincidence. Computational Linguistics, 19(1), 61-74. Retrieved from https://www.aclweb.org/anthology/J93-1003

Fairclough, N. (2001). Language and power. Longman.

Flynn, C. (2009). ALT furniture: A look at dispatch ALT contracts. The Language Teacher, 33(5),

39-40. Retrieved from https://jalt-publications.org/tlt/departments/job-info-centre/articles/532alt-furniture-look-dispatch-alt-contracts

Hougham, D. G. C., Walter, B. R., \& Sponseller, A. C., (2017). Practicalities of team teaching: Recent research and experience in Japan. In P. Clements, A. Krause, \& H. Brown (Eds.), Transformation in language education (pp. 135-145). Tokyo: JALT. Retrieved from https://jalt-publications.org/files/ pdf-article/jalt2016-pcp-018.pdf

Kano, A., Sonoda, A., Schultz, D., Usukura, A., Suga, K., \& Yasu, Y., (2016). Barriers to effective team teaching with ALTs. In P. Clements, A. Krause, \& H. Brown (Eds.), Focus on the learner (pp. 74-82). Tokyo: JALT. Retrieved from https://jalt-publications.org/sites/default/files/pdf-article/jalt2015pcp_011.pdf

Leuckert, S., \& Leuckert, M. (2020). Towards a digital sociolinguistics: Communities of practice on reddit. In S. Rüdiger \& D. Dayter (Eds.), Corpus approaches to social media (pp. 15-40). John Benjamins.

Locher, M.A., \& Limberg, H. (2012). Introduction to advice in discourse. In H. Limberg \& M.A. Locher (Eds.), Advice in discourse (pp. 1-27). John Benjamins. 
Mackenzie, J. (2017). Identifying informational norms in mumsnet talk: A reflexive-linguistic approach to internet research ethics. Applied Linguistics Review, 8(2-3), 293-314. https://doi. org/10.1515/applirev-2016-1042

McConnell, D. L. (2000). Importing diversity: Inside Japan's JET program. University of California Press. MEXT. (2016a). 平成27年度英語教育実施状況調查 (小学校) の結果概要 [Summary of results from the 2015 English education implementation status survey (elementary school)]. Retrieved January 6 , 2021, from https://www.mext.go.jp/component/a_menu/education/detail/__icsFiles/afieldfi le/2016/04/05/1369254_1_1.pdf

MEXT. (2016b). 平成27年度英語教育実施状況調查 (中学校) の結果概要 [Summary of results from the 2015 English education implementation status survey (junior high school)]. Retrieved January 6, 2021, from https://www.mext.go.jp/component/a_menu/education/detail/__icsFiles/afieldfi le/2016/04/05/1369254_2_1.pdf

MEXT. (2016c). 平成27年度英語教育実施状況調查 (高学校) の結果概要 [Summary of results from the 2015 English education implementation status survey (senior high school)]. Retrieved January 6, 2021, from https://www.mext.go.jp/component/a_menu/education/detail/_icsFiles/afieldfi le/2016/04/05/1369254_3_1.pdf

Nuske, K. (2014). "It is very hard for teachers to make changes to policies that have become so solidified": Teacher resistance at corporate eikaiwa franchises in Japan. Asian EFL Journal, 16(2), 105-131. Retrieved from https://www.asian-efl-journal.com/main-editions-new/it-is-very-hardfor-teachers-to-make-changes-to-policies-that-have-become-so-solidified-teacher-resistance-atcorporate-eikaiwa-franchises-in-japan/

OECD. (2021). OECD.stat: Average annual wages. Retrieved March 11, 2021 from https://stats.oecd. org/Index.aspx?DataSetCode=AV_AN_WAGE

O'Halloran, K. (2010). How to use corpus linguistics in the study of media discourse. In A. O'Keeffe \& M. McCarthy (Eds.), The Routledge handbook of corpus linguistics (pp. 563-577). Routledge.

Ohtani, C. (2010). Problems in the assistant language teacher system and English activity at Japanese public elementary schools. Educational Perspectives, 43(1-2), 38-45. Retrieved from https://eric.ed.gov/?id=EJ912113

Scott, M. (2010). What can corpus software do? In A. O'Keeffe \& M. McCarthy (Eds.), The Routledge handbook of corpus linguistics (pp. 136-151). Routledge.

Sinclair, J. (1999). A way with common words. In H. Hasselgård \& S. Oksefjell (Eds.), Out of corpora Studies in honour of Stig Johansson (pp. 157-180). Rodopi.

Widdowson, H. G. (1998). Review article: The theory and practice of critical discourse analysis. Applied Linguistics, 19(1), 136-151. https://doi.org/10.1093/applin/19.1.136

Yokoyama, T. (2018). Official and realized hiring policy of assistant language teachers in Japan. In J. Crandall \& K. M. Bailey (Eds.), Global perspectives on language education policies (pp. 106-116). Routledge. 